University for Business and Technology in Kosovo

UBT Knowledge Center

UBT International Conference

2017 UBT International Conference

Oct 28th, 11:00 AM - 12:30 PM

\title{
Control of Vitamin C (ascorbic acid) in non-alcoholic and fresh drinks
}

\author{
Durim Alija \\ University of Tetova, durim.alija@unite.edu.mk \\ Eljesa Ziberi \\ University of Tetova \\ Gafur Xhabiri \\ University of Tetova \\ Xhezair Idrizi \\ University of Tetova \\ Namik Durmishii \\ University of Tetova
}

See next page for additional authors

Follow this and additional works at: https://knowledgecenter.ubt-uni.net/conference

Part of the Food Science Commons

\section{Recommended Citation}

Alija, Durim; Ziberi, Eljesa; Xhabiri, Gafur; Idrizi, Xhezair; Durmishii, Namik; and Ferati, Ismail, "Control of Vitamin C (ascorbic acid) in non-alcoholic and fresh drinks" (2017). UBT International Conference. 157. https://knowledgecenter.ubt-uni.net/conference/2017/all-events/157

This Event is brought to you for free and open access by the Publication and Journals at UBT Knowledge Center. It has been accepted for inclusion in UBT International Conference by an authorized administrator of UBT Knowledge Center. For more information, please contact knowledge.center@ubt-uni.net. 


\section{Presenter Information}

Durim Alija, Eljesa Ziberi, Gafur Xhabiri, Xhezair Idrizi, Namik Durmishii, and Ismail Ferati 


\title{
Control of Vitamin C (ascorbic acid) in non-alcoholic and fresh drinks
}

\author{
Durim Alija ${ }^{1}$, Eljesa Ziberi ${ }^{1}$, Xhezair Idrizi ${ }^{1}$, Ismail Ferati ${ }^{1}$ \\ ${ }^{1}$ Faculty of Food Technology and Nutrition, University of Tetova, Tetovo, \\ Macedonia \\ durim.alija@unite.edu.mk
}

\begin{abstract}
This paper deals with the method of determining vitamin $\mathrm{C}$ in non-alcoholic and fresh drinks, also deals with its importance in the human body and elaborates the problematic consumption of vitamin $\mathrm{C}$ in the daily dose of adult people. Lack of vitamin $\mathrm{C}$ manifests itself with: pain and rapid muscle fatigue, increased infections, anemia, osteoporosis, hemorrhage, etc. According to the highest amount of vitamin $\mathrm{C}$ in $100 \mathrm{~g}$, there are: pepper $128 \mathrm{mg}, 113 \mathrm{mg}$ cabbage, $90 \mathrm{mg}$ kiwi, $59 \mathrm{mg}$ strawberries, $53 \mathrm{mg}$ lemon, $51 \mathrm{mg}$ spinach, $38 \mathrm{mg}$ grapefruit, $23 \mathrm{mg}$ tomatoes. Ascorbic acid and its sodium, potassium and calcium salts are widely used as an antioxidant food additive. Relevant food additives from ascorbic acid (E-numbers) are: E300 ascorbic acid, E301 - sodium ascorbate, E302 - calcium ascorbate, E303 - potassium ascorbate.
\end{abstract}

Keywords: vitamin C, daily need, lack of vitamin C, ascorbic acid, food additives, E-numbers

\section{INTRODUCTION}

Vitamin $\mathrm{C}$ attracts attention of the research community and consumers as a nutrient with a broad biological activity and importance for human health. It is a white, crystalline, odourless, watersoluble compound. Main sources of vitamin $\mathrm{C}$ are fruits and vegetables (green and red peppers, collard greens, broccoli, spinach, tomatoes, potatoes, strawberries, oranges, etc.). Vitamin C supports the absorption of iron and the formation of collagen. Vitamin $\mathrm{C}$ is often added to foods not only as a nutrient (to make up for processing losses) and an antioxidant ${ }^{[1]}$, but it is added also in order to prevent the browning of fresh and canned fruits and vegetables.

Vitamin $\mathrm{C}$ is often added as a fortificant to fruit juices, fruit-flavoured drinks, juice added soda waters, dry cocktails or beverages, cereal-based products, and milk. General principles for the addition of essential nutrients to foods are given by the Codex Alimentarius Commission. The Codex definition of fortification is ,the addition of one or more essential nutrients to a food whether or not it is normally contained in the food, for the purpose of preventing or correcting a demonstrated deficiency of one or more nutrients in the population or specific population groups“ [2].

\footnotetext{
${ }^{1}$ Kirby, C. J. - Whittle, C. J. - Rigby, N. - Coxon, D. T. - Law, B. A.: Stabilization of ascorbic acid by microencapsulation in liposomes. International Journal of Food Science and Technology, 26, 1991

${ }^{2}$ Food fortification: technology and quality control.Report of an FAO technical meeting held in Rome, 20-23 November '95
} 
Ascorbic acid is recognized to be one of the most heat sensitive nutrients in foods, therefore, it is a marker of the loss of other nutrients ${ }^{[3}$. The aim of this article is to review the papers on ascorbic acid degradation in fortified foods at various storage temperatures. For the sake of comparing the published data and finding relevant trends, the rate constants of degradation are calculated.

\section{Recommended intakes}

Intake recommendations for vitamin $\mathrm{C}$ and other nutrients are provided in the Dietary Reference Intakes (DRIs) developed by the Food and Nutrition Board (FNB) at the Institute of Medicine (IOM) of the National Academies (formerly National Academy of Sciences) ${ }^{[4]}$. DRI is the general term for a set of reference values used for planning and assessing nutrient intakes of healthy people. These values, which vary by age and gender ${ }^{4}$, include:

- Recommended Dietary Allowance (RDA): average daily level of intake sufficient to meet the nutrient requirements of nearly all $(97 \%-98 \%)$ healthy individuals.

- $\quad$ Adequate Intake (AI): established when evidence is insufficient to develop an RDA and is set at a level assumed to ensure nutritional adequacy.

- Tolerable Upper Intake Level (UL): maximum daily intake unlikely to cause adverse health effects ${ }^{[4]}$.

Table 1 lists the current RDAs for vitamin $\mathrm{C}^{4}$. The RDAs for vitamin $\mathrm{C}$ are based on its known physiological and antioxidant functions in white blood cells and are much higher than the amount required for protection from deficiency ${ }^{[5]}$. For infants from birth to 12 months, the FNB established an AI (Adequate Intake) for vitamin C that is equivalent to the mean intake of vitamin $\mathrm{C}$ in healthy, breastfed infants.

Table 1: Recommended Dietary Allowances (RDAs) for Vitamin C

\begin{tabular}{|l|l|l|l|}
\hline AGE & MALE & FEMALE & PREGNANCY \\
\hline 0-6 months & $40 \mathrm{mg}$ & $40 \mathrm{mg}$ & \\
\hline $7-12$ months & $50 \mathrm{mg}$ & $50 \mathrm{mg}$ & \\
\hline $1-3$ year & $15 \mathrm{mg}$ & $15 \mathrm{mg}$ & \\
\hline $4-8$ year & $25 \mathrm{mg}$ & $25 \mathrm{mg}$ & \\
\hline 9-13 year & $45 \mathrm{mg}$ & $45 \mathrm{mg}$ & \\
\hline $14-18$ year & $75 \mathrm{mg}$ & $65 \mathrm{mg}$ & $80 \mathrm{mg}$ \\
\hline 19+ year & $90 \mathrm{mg}$ & $75 \mathrm{mg}$ & $85 \mathrm{mg}$ \\
\hline SMOKERS & $\begin{array}{l}\text { Individuals who smoke require } 35 \mathrm{mg} / \text { day more } \\
\text { vitamin C than nonsmokers. }\end{array}$ \\
\hline
\end{tabular}

${ }^{3}$ Esteve, M. J. - Frigola, A. - Martorell, L. - Rodrigo, C.: Kinetics of green asparagus ascorbic acid heated in a high-temperature thermoresistometer

${ }^{4}$ Institute of Medicine. Food and Nutrition Board. Dietary Reference Intakes for Vitamin C, Selenium, and Carotenoids

${ }_{5}^{5}$ Jacob RA, Sotoudeh G. Vitamin C function and status in chronic disease. 


\subsection{Sources of Vitamin C}

Fruits and vegetables are the best sources of vitamin C (see Table 2) [6]. Citrus fruits, tomatoes and tomato juice, and potatoes are major contributors of vitamin $\mathrm{C}$ to the American diet. Other good food sources include red and green peppers, kiwifruit, broccoli, strawberries, Brussels sprouts, and cantaloupe (see Table 2). Although vitamin C is not naturally present in grains, it is added to some fortified breakfast cereals. The vitamin $\mathrm{C}$ content of food may be reduced by prolonged storage and by cooking because ascorbic acid is water soluble and is destroyed by heat [7]. Steaming or microwaving may lessen cooking losses. Fortunately, many of the best food sources of vitamin $\mathrm{C}$, such as fruits and vegetables, are usually consumed raw. Consuming five varied servings of fruits and vegetables a day can provide more than $200 \mathrm{mg}$ of vitamin C.

Table 2: Selected Food Sources of Vitamin C ${ }^{[8]}$

\begin{tabular}{|l|l|l|}
\hline Fruits, vegetables \& drinks & Mg/serving & Percent $\%$ \% $V^{*}$ \\
\hline Red pepper & 95 & 158 \\
\hline Orange juice, cup & 93 & 155 \\
\hline Orange, 1 medium & 70 & 117 \\
\hline Grapefruit juice, cup & 70 & 117 \\
\hline Green pepper & 60 & 100 \\
\hline Broccoli & 51 & 85 \\
\hline Strawberries, fresh & 49 & 82 \\
\hline Tomato juice & 33 & 55 \\
\hline Spinach cooked & 9 & 15 \\
\hline
\end{tabular}

*DV = Daily Value. DVs were developed by the U.S. Food and Drug Administration (FDA) to help consumers compare the nutrient contents of products within the context of a total diet. The DV for vitamin $\mathrm{C}$ is $60 \mathrm{mg}$ for adults and children aged 4 and older. The FDA requires all food labels to list the percent DV for vitamin C. Foods providing $20 \%$ or more of the DV are considered to be high sources of a nutrient.

\section{VITAMIN C INTAKES AND STATUS}

According to the 2001-2002 National Health and Nutrition Examination Survey (NHANES), mean intakes of vitamin $\mathrm{C}$ are $105.2 \mathrm{mg} /$ day for adult males and $83.6 \mathrm{mg} / \mathrm{day}$ for adult females, meeting the currently established RDA for most nonsmoking adults [9]. Mean intakes for children and adolescents aged 1-18 years range from $75.6 \mathrm{mg} /$ day to $100 \mathrm{mg} /$ day, also meeting the RDA for these age groups. Although the 2001-2002 NHANES analysis did not include data for breastfed infants and toddlers, breastmilk is considered an adequate source of vitamin C . Use of vitamin C-containing supplements is also relatively common, adding to the total vitamin C intake from food and beverages. NHANES data from 1999-2000 indicate that approximately $35 \%$ of adults take multivitamin supplements (which typically contain vitamin $\mathrm{C}$ ) and $12 \%$ take a

${ }^{6}$ U.S. Department of Agriculture, Agricultural Research Service. 2011. USDA National Nutrient Database for Standard Reference, Release 24

${ }^{7}$ Weinstein M, Babyn P, Zlotkin S. An orange a day keeps the doctor away: scurvy in the year 2000

${ }^{8}$ Also in the $6^{\text {th }}$ Footnote

${ }^{9}$ Moshfegh A, Goldman J, Cleveland L. What We Eat in America, NHANES 2001-2002: Usual Nutrient Intakes from Food Compared to Dietary Reference Intakes 
separate vitamin C supplement. According to 1999-2002 NHANES data, approximately $29 \%$ of children take some form of dietary supplement that contains vitamin $\mathrm{C}^{[10]}$.

Vitamin $C$ status is typically assessed by measuring plasma vitamin $C$ levels ${ }^{[11}$. Other measures, such as leukocyte vitamin $\mathrm{C}$ concentration, could be more accurate indicators of tissue vitamin $\mathrm{C}$ levels, but they are more difficult to assess and the results are not always reliable.

\section{Vitamin $\mathrm{C}$ and health}

Due to its function as an antioxidant and its role in immune function, vitamin $\mathrm{C}$ has been promoted as a means to help prevent and/or treat numerous health conditions. This section focuses on four diseases and disorders in which vitamin $\mathrm{C}$ might play a role: cancer (including prevention and treatment), cardiovascular disease, age-related macular degeneration (AMD) and cataracts, and the common cold.

\section{Health risks from excessive Vitamin C}

Vitamin $\mathrm{C}$ has low toxicity and is not believed to cause serious adverse effects at high intakes. The most common complaints are diarrhea, nausea, abdominal cramps, and other gastrointestinal disturbances due to the osmotic effect of unabsorbed vitamin $C$ in the gastrointestinal tract ${ }^{[12]}$. Other reported effects of high intakes of vitamin $\mathrm{C}$ include reduced vitamin $\mathrm{B}_{12}$ and copper levels, accelerated metabolism or excretion of ascorbic acid, erosion of dental enamel, and allergic responses. However, at least some of these conclusions were a consequence of assay artifact, and additional studies have not confirmed these observations .

The FNB has established ULs for vitamin C that apply to both food and supplement intakes (Table 3) ${ }^{[13]}$. Long-term intakes of vitamin $C$ above the UL may increase the risk of adverse health effects. The ULs do not apply to individuals receiving vitamin $\mathrm{C}$ for medical treatment, but such individuals should be under the care of a physician ${ }^{[14]}$.

Table 3: Tolerable Upper Intake Levels (ULs) for Vitamin C

\begin{tabular}{|l|l|l|l|}
\hline AGE & MALE & FEMALE & PREGNANCY \\
\hline $1-3$ year & $400 \mathrm{mg}$ & $400 \mathrm{mg}$ & \\
\hline $4-8$ year & $650 \mathrm{mg}$ & $650 \mathrm{mg}$ & \\
\hline 9-13 year & $1200 \mathrm{mg}$ & $1200 \mathrm{mg}$ & \\
\hline $14-18$ year & $1800 \mathrm{mg}$ & $1800 \mathrm{mg}$ & $2000 \mathrm{mg}$ \\
\hline 19+ year & $2000 \mathrm{mg}$ & $2000 \mathrm{mg}$ & $2000 \mathrm{mg}$ \\
\hline
\end{tabular}

${ }^{10}$ Picciano MF, Dwyer JT, Radimer KL, Wilson DH, Fisher KD, Thomas PR, et al. Dietary supplement use among infants, children, and adolescents in the United States, 1999-2002

${ }^{11}$ Bates CJ. Bioavailability of vitamin C. Eur J Clin Nutr 1997;51 (Suppl 1):S28-33.

${ }^{12}$ Francescone MA, Levitt J. Scurvy masquerading as leukocytoclastic vasculitis: a case report and review of the literature

${ }^{13}$ Also in the $4^{\text {th }}$ Footnote

${ }^{14}$ Also in the $4^{\text {th }}$ Footnote 


\section{METHOD OF CONTROLLING VITAMIN C}

Importance of vitamin $\mathrm{C}$ for our health leads us to explore the methods of detection of Vitamin $\mathrm{C}$ in food. One way to determine the amount of vitamin $\mathrm{C}$ in food is by redox titration using iodine. As the iodine is added during the titration, the ascorbic acid is oxidized to dehydroascorbic acid, while the iodine is reduced to iodide ions.

$$
\text { Ascorbic acid }+\mathrm{I}_{2} \longrightarrow 2 \mathrm{I}^{-}+\text {dehydroascorbic acid }
$$

As it is demonstrated in the below example:

$$
\mathrm{C}_{6} \mathrm{H}_{8} \mathrm{O}_{6}+\mathrm{I}_{3}{ }^{-}+\mathrm{H}_{2} \mathrm{O} \rightarrow \mathrm{C}_{6} \mathrm{H}_{6} \mathrm{O}_{6}+3 \mathrm{I}^{-}+2 \mathrm{H}^{+}
$$

As long as vitamin $\mathrm{C}$ is present in the solution, the triiodide is converted to the iodide ion very quickly. However, when the all the vitamin $\mathrm{C}$ is oxidized, iodine and triiodide will be present, which react with starch to form a blue-black complex. The blue-black color is the endpoint of the titration.

This titration procedure is appropriate for testing the amount of vitamin $\mathrm{C}$ in vitamin $\mathrm{C}$ tablets, juices, and fresh, frozen, or packaged fruits and vegetables. The titration can be performed using just iodine solution and not iodate, but the iodate solution is more stable and gives a more accurate result.

The goal of this laboratory exercise is to determine the amount of vitamin $\mathrm{C}$ in samples, such as fruit juice.

\section{EXPERIMENTAL PROCEDURE}

For right results from this experimental procedure, we need to prepare the solutions very accurately. The key solutions for this experimental are:

3.2 Starch indicator solution: $(0.5 \%)$.

To prepare the starch indicator we need to weigh $0.50 \mathrm{~g}$ of soluble starch and add it to $50 \mathrm{~mL}$ of near boiling water in a $100-\mathrm{mL}$ conical flask. Stir to dissolve and we use it cooled.

\section{IODINE SOLUTION}

For iodine solution we weigh $5 \mathrm{~g}$ of potassium iodide and $0.268 \mathrm{~g}$ potassium iodate into a 200 $\mathrm{mL}$ of distilled water. Then we add $30 \mathrm{ml}$ of $3 \mathrm{M}$ sulfuric water. Finally, we transfer iodine solution to a $500 \mathrm{ml}$ volumetric flask, making sure to rinse all traces of solution into the volumetric flask using distilled water.

\section{VITAMIN C STANDARD SOLUTION}

Dissolve $0.250 \mathrm{~g}$ vitamin C (ascorbic acid) in $100 \mathrm{ml}$ distilled water. Dilute to $250 \mathrm{ml}$ with distilled water in a volumetric flask. Label the flask as your vitamin $\mathrm{C}$ standard solution. Beside the accordingly making solutions, it's important to make the right Standardization of Solutions. For standardization of solution we need to add $25.00 \mathrm{ml}$ of vitamin C standard solution to a $125 \mathrm{ml}$ Erlenmeyer flask. Then we add drops of $1 \%$ starch solution. Finally, we note the amount of iodate solution used for titration.

*From the titration of the standard vitamin $\mathrm{C}$ solution, these data were obtained:

1. from the first titration we spend $\mathbf{2 4} \mathbf{m l}$ iodate solution

2. from the second titration we spend $\mathbf{2 2} \mathbf{m l}$ iodate solution 
3. from the third we spend $\mathbf{2 0} \mathrm{ml}$ iodate solution

Now we calculate the average value of iodate solution:

$V=\frac{24 m l+22 m l+20 m l}{3}=\mathbf{2 2} \mathbf{m l}$ iodine solution was used to titrate the standard vitamin C solution

\section{TITRATING JUICE SAMPLES}

1. We add $25.00 \mathrm{ml}$ of juice sample to a $125 \mathrm{ml}$ Erlenmeyer flask.

2. We have titrated until the endpoint is reached. (Adding iodine solution until you get a color that persists longer than 20 seconds.)

3. We have repeat 3 times the same titration.

\section{TITRATING REAL FRUIT}

1. We have added $10.00 \mathrm{ml}$ of Real Lemon into a $125 \mathrm{ml}$ Erlenmeyer flask.

2. For this titrate we have used three measurements.

\section{OUR SAMPLES TESTED:}

Titrating juice samples:

From juice we have samples from two local producers:

1. Fructal multivamin $200 \mathrm{ml}$

2. Bravo orange $500 \mathrm{ml}$

\section{Titrating real fruit samples:}

From juice fresh fruit we have taken samples from two types:

1. Lemon juice

2. Orange juice

\section{How we have calculated Vitamin C}

1. We have calculated the $\mathrm{ml}$ of titrant used for each flask. Take the measurements obtained and average them.

average volume $=$ total volume $/$ number of trials

2. Then we determine how much titrant was required for your standard. Example with $6 \mathrm{ml}$ spent of iodine solution in titration:

$22 X=1.5$

$$
\frac{22 \mathrm{ml} \text { iodine solution }}{0.250 \mathrm{~g} \text { of Vitamin } C}=\frac{6.00 \mathrm{ml} \text { iodine solution }}{X \mathrm{ml} \text { of Vitamin } C}
$$

$X=0.068 \mathrm{~g}$ Vitamin $C$ in that sample

3. Also, we must have finally calculation in mind for the volume of our sample, so we can make other calculations, such as grams per liter. For a $25-\mathrm{ml}$ juice sample, for example: 


$$
\frac{0.068 \mathrm{~g}}{25 \mathrm{ml}}=\frac{0.068 \mathrm{~g}}{0.025 \mathrm{~L}}=2.72 \mathrm{~g} / \mathrm{L} \text { of Viramin } C \text { in that sample }
$$

RESULTS:

\section{Data processing:}

From standard vitamin $\mathrm{C}$ titration are obtained these data:

1. From the first titration we spent:
I. $\quad 3.3 \mathrm{ml}$ iodine solution
II. $\quad 3.4 \mathrm{ml}$ iodine solution
III. $\quad 3.5 \mathrm{ml}$ iodine solution

2. From the se second titration we spent:
I. $\quad 3.1 \mathrm{ml}$ iodine solution
II. $\quad 2.9 \mathrm{ml}$ iodine solution
III. $\quad 3.3 \mathrm{ml}$ iodine solution

3. From the third titration we spent:
I. $\quad 5.0 \mathrm{ml}$ iodine solution
II. $\quad 5.1 \mathrm{ml}$ iodine solution

III. $\quad 5.5 \mathrm{ml}$ iodine solution

4. From the fourth titration we spent:
I. $\quad 4.3 \mathrm{ml}$ iodine solution
II. $\quad 4.7 \mathrm{ml}$ iodine solution
III. $\quad 4.8 \mathrm{ml}$ iodine solution

\section{TITRATION CALCULATIONS}

\section{For the first titration (Fructal multivitamin)}

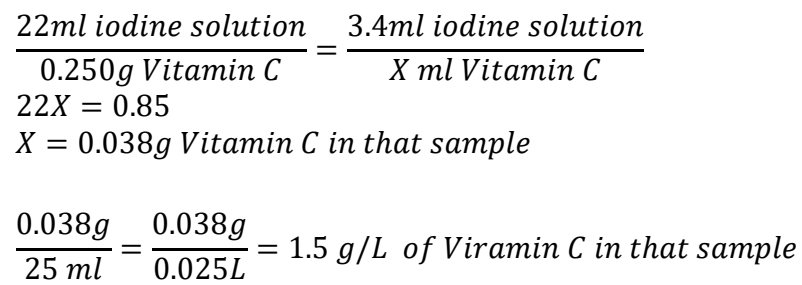

\section{For the second titration (Bravo Orange)}

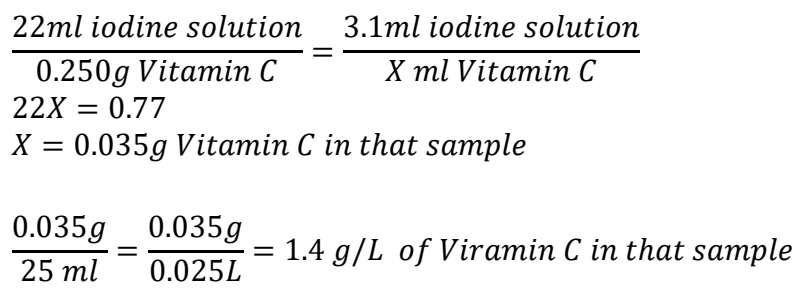




\title{
For the third titration (Lemon juice)
}

\author{
$\frac{22 \mathrm{ml} \text { iodine solution }}{0.250 \mathrm{~g} \text { Vitamin } C}=\frac{5.2 \mathrm{ml} \text { iodine solution }}{X \mathrm{ml} \text { Vitamin } C}$ \\ $22 X=1.3$ \\ $X=0.059 \mathrm{~g}$ Vitamin $C$ in that sample \\ $\frac{0.059 \mathrm{~g}}{10 \mathrm{ml}}=\frac{0.059 \mathrm{~g}}{0.010 \mathrm{~L}}=5.9 \mathrm{~g} / \mathrm{L}$ of Viramin C in that sample
}

\section{For the fourth titration (Orange juice)}

\author{
$\frac{22 \mathrm{ml} \text { iodine solution }}{0.250 g V \text { itamin } C}=\frac{4.6 \mathrm{ml} \text { iodine solution }}{X \mathrm{ml} V \text { itamin } C}$ \\ $\frac{0.250 \mathrm{~g} \text { Vitamin } C}{X \mathrm{ml} \text { Vitamin } C}$ \\ $22 X=1.15$ \\ $X=0.052 g$ Vitamin $C$ in that sample \\ $\frac{0.052 \mathrm{~g}}{10 \mathrm{ml}}=\frac{0.052 \mathrm{~g}}{0.010 \mathrm{~L}}=5.2 \mathrm{~g} / \mathrm{L}$ of Viramin C in that sample
}

\section{DISCUSSION}

To achieve results for quantity of vitamin $\mathrm{C}$ in food we could use also the developed method who proved us with accuracy in vitamin $\mathrm{C}$ determination in fruit juice. Although other volumetric methods are more sensitive than developed methods for determining ascorbic acid, volumetric methods can be used with very good results to analyze ascorbic acid in fruit juice. Classical volumetric method to determinate the concentrations of ascorbic acid in fruit juice determined is in good agreement with the data reported in literature regarding the content of ascorbic acid in citrus fruits. The reported values for lemon are $5.9 \mathrm{~g} / \mathrm{L}$ juice fruit, for multivitamin juice the result was $1.5 \mathrm{~g} / \mathrm{L}$, in bravo juice the result was $1.4 \mathrm{~g} / \mathrm{L}$. Other results were content of $5.2 \mathrm{~g} / \mathrm{L}$ in fresh orange juice. With the result we wanted to prove that with volumetric method we can successfully make analyzes in food industry, for assessing the vitamin $\mathrm{C}$ content in natural fruit juice and soft drinks. This method is easy to implement and enables companies to have an internal control of vitamin $\mathrm{C}$ in soft drinks in or case. The results prove why, recently, this technique has been more and more preferred to the previously applied methods, as it is characterized by accuracy, rapidity, good specificity, and sensitivity, and also by the simplicity of the required equipment and procedure.

\section{CONCLUSION}

Knowing the importance of daily vitamin $\mathrm{C}$ content in our body, we decided to analyze two types of products we consume every day. We have analyzed fresh citrus fruits and soft drinks. Ultimately, Vitamin C is arguably one of the most important vitamins for health benefits and life. Its various functions prove it to be a versatile substance that acts to support many aspects of the body. With our study we wanted to compare the real content of Vitamin C in soft drinks and the label of the product. So, with the analyzed of fresh juice we wanted to know the real content of vitamin $\mathrm{C}$ in fresh fruits from our stores. Also, our goals were to see how much Vitamin C contain the juice with concentrate base and those one from fresh fruits. 


\section{REFERENCES}

1. Kirby, C. J. - Whittle, C. J. - Rigby, N. - Coxon, D. T. - Law, B. A.: Stabilization of ascorbic acid by microencapsulation in liposomes. International Journal of Food Science and Technology, 26, 1991

2. Food fortification: technology and quality control.Report of an FAO technical meeting held in Rome, 20-23 November 1995 [online]. FAO Food And Nutrition Paper - 60. Rome : FAO,1996[cit.2006-03-20]. www.fao.org/docrep/W2840E/ W2840E00.htm.

3. The Chemistry of its Components,2009 Tom Kaltejt pg.332-338

4. Esteve, M. J. - Frigola, A. - Martorell, L. - Rodrigo, C.: Kinetics of green asparagus ascorbic acid heated in a high-temperature thermoresistometer. Zeitschrift für Lebensmittel Unterschung Forschung, A 208, 1999, pp. 144-147.

5. Institute of Medicine. Food and Nutrition Board. Dietary Reference Intakes for Vitamin C, Selenium, and Carotenoids . Washington, DC: National Academy Press, 2000.

6. Jacob RA, Sotoudeh G. Vitamin C function and status in chronic disease. Nutr Clin Care 2002;5:66-74. [PubMed abstract]

7. Francescone MA, Levitt J. Scurvy masquerading as leukocytoclastic vasculitis: a case report and review of the literature. Cutis 2005;76:261-6. [PubMed abstract]

8. Stephen R, Utecht T. Scurvy identified in the emergency department: a case report. J Emerg Med 2001;21:235-7. [PubMed abstract]

9. Moshfegh A, Goldman J, Cleveland L. What We Eat in America, NHANES 2001-2002: Usual Nutrient Intakes from Food Compared to Dietary Reference Intakes DC: U.S. Department of Agriculture, Agricultural Research Service, 2005.

10. Bates CJ. Bioavailability of vitamin C. Eur J Clin Nutr 1997;51 (Suppl 1):S28-33.

11. Radimer K, Bindewald B, Hughes J, Ervin B, Swanson C, Picciano MF. Dietary supplment use by US adults: data from the National Health and Nutrition Examination Survey, 1999-2000. Am J Epidemiol 2004;160:339-49

12. Picciano MF, Dwyer JT, Radimer KL, Wilson DH, Fisher KD, Thomas PR, et al. Dietary supplement use among infants, children, and adolescents in the United States, 1999-2002. Arch Pediatr Adolesc Med 2007;161:978-85

13. U.S. Department of Agriculture, Agricultural Research Service. 2011. USDA National Nutrient Database for Standard Reference, Release 24. Nutrient Data Laboratory Home Page, http://www.ars.usda.gov/ba/bhnrc/ndl

14. Weinstein M, Babyn P, Zlotkin S. An orange a day keeps the doctor away: scurvy in the year 2000. Pediatrics 2001;108:E55. 